\title{
Indonesia-Taiwan Relations In One Village One Product (Ovop) In Pelaga Bali Province 2011-2016
}

\author{
Ni Luh Kerti ${ }^{1}$, Yoyoh Rohaniah ${ }^{2}$ \\ \{niluhkerti@dsn.moestopo.ac.id ${ }^{1}$, yoyohr@dsn.moestopo.ac.id ${ }^{2}$ \} \\ 1,2 Faculty of Social Science and Political Science, Universitas Prof. Dr. Moestopo
}

(Beragama), Jakarta Indonesia

\begin{abstract}
One of the collaborations carried out through the Ministry of Cooperatives and SMEs with Taiwan is in the form of the One Village One Product (OVOP) program. The OVOP program in Bali Province is a government effort to empower farmers with the OVOP pattern. The purpose of this study was to describe the cooperation between Indonesia and Taiwan in the OVOP program in Bali Province. This type of research is descriptive with a qualitative approach. Data collection techniques include interviewing and documentation. While the technique of analyzing data starts from reducing data to concluding. The results of the analysis of the research findings indicate that the OVOP Program implemented in Bali Province as seen from all aspects has gone well. The constraints encountered in the implementation of the program are the difficulty in changing the mindset of farming patterns from traditional to modern, pessimistic of farmers on new programs and related to extreme weather that is still difficult to overcome affecting the quality of harvest.
\end{abstract}

Keywords: Ovop program, empower farmers, collaborations, Bali.

\section{Introduction}

Various kinds of international cooperation carried out by a country towards other countries, one of the cooperation that is being the focus of attention of both large and small countries is cooperation in the economic field regarding strengthening in the field of Small and Medium Enterprises (UKM) which is one of the important schedule in the APEC meeting in United States in 2011.

There are two focuses in discussing the new strategy, namely (i) expansion of trade and investment, and (ii) the creation of quality growth. SME development is a central issue in the second focus, namely the creation of quality growth. In the SOM 1 meeting, the issue of SME development was discussed in various APEC working group and seminar meetings. Group on Services (GOS) is included in a working group that discusses the issue of SME development in its meetings. In addition, GOS also scheduled the holding of a special seminar related to the role of the service sector in encouraging SMEs with the theme "Addressing Business Constraints of SMEs through Services" on March 2, 2011. [1]

The implementation of OVOP in Indonesia was initiated in 2006 by the Ministry of Industry which was then marked by the issuance of the Presidential Instruction concerning the acceleration of real sector development and empowerment of Micro, Small and Medium Enterprises (MSMEs) and the Minister of Industry regulations on improving the effectiveness of Small and Medium Industries (IKM) through the OVOP approach interrelated to encourage local small and medium industry products to be able to compete in the global market. OVOP 
implementation in Indonesia follows a regional development program concept, both in the form of villages, sub-districts, cities, and subsequently chooses a main product that results from the creativity of the village community. $\{2\}$

The implementation of the OVOP program supported by Presidential Instruction No. 6 of 2007 concerning the Policy for Accelerating the Development of the Real Sector and Empowering Micro, Small and Medium Enterprises (MSMEs) requires farmers / Micro, Small and Medium Enterprises who wish to obtain technical, capital, marketing training, guidance and others must be members of a cooperative. So that the implementation of the OVOP program is managed by local cooperatives as a forum for farmers / Micro Small and Medium Entrepreneurs in developing their business. In this case, the Indonesian government through the Ministry of Cooperatives and SMEs works with several countries in the implementation of the OVOP program so that it can run more optimally. Taiwan as one of the countries that cooperates in the OVOP program. Indonesian Chamber of Commerce and Industry (Kadin) holds an economic meeting with Taiwan, at Hotel Mulia Jakarta, Tuesday, June 16, 2009. [3]

\section{Method}

In this study, the author uses a type of qualitative research where according to Creswell qualitative research is a study that begins by stating assumptions using a theoretical point of view to formulate and solve social problems. In solving these problems researchers will use a qualitative approach by collecting data from the parties involved in the research. Which in the end will bring up the opinions of the parties concerned with the research, so that it will bring up a description of the existing problems, which in the future will be used as a guide to solve these problems. Creswell said that qualitative research uses documents, interviews and observations on the behavior of related actors to collect data. [4]

Then, in analyzing the phenomena that exist the writer will use the method of data collection carried out by interviewing parties related to the phenomenon in order to obtain data from primary sources which in the future can be accounted for the correctness of the data. Furthermore, the writer also uses literature studies related to these phenomena such as books, magazines, articles, scientific journals, newspapers, seminar papers, theses, data from the internet and documents issued by a particular institution to obtain secondary data.

\section{Result And Discussion}

Indonesia and Taiwan do not have diplomatic relations, because Indonesia adheres to the One China Policy. But the cooperation between the two parties went well, even showing a lot of progress in the fields of economy, trade, education and employment. [5]

Indonesia is an important Taiwan trading partner. To face globalization competition, transparency in trade and free markets, as well as changes in trade networks that are increasingly fast, an organization is formed, TAITRA (Taiwan External Trade Development Council). TAITRA (Taiwan External Trade Development Council) is a merger of legal entity organizations under the auspices of the Foreign Trade Bureau with the aim of helping Taiwan's industry expand trade. At present there are almost 50 TAITRA (Taiwan External Trade Development Council) offices abroad that are located in various parts of the world. Hoping that the presence of TAITRA (Taiwan External Trade Development Council) will further enhance international marketing capabilities from various angles, provide the most fast and effective services, continue to collaborate with entrepreneurs for Taiwan's stable economic development. [6] 
The main principles in the OVOP program are (1) Local yet Global, that is, an area basically has been endowed with abundant natural resources, therefore people in the area must be smart in processing their resources. In the processing process, the community must innovate to create a product that is acceptable in the global arena by highlighting the local culture in the product. [7]

Then the principle to (2) is Self-reliances and Creativity, that is, people must be creative in managing their resources. In this case, the government supports the community to improve their capabilities by providing counseling so that the community can manage the resources they have as well as possible. Then, people are also free to do creativity to add more value to their products. As well, the government also helps to provide market access to local communities.

Then the principle (3) is Human Resources Development, namely the OVOP movement is not always related to how to develop a product but also related to the development of human resources. In this case, OVOP aims to transfer entrepreneurial capabilities, product development, business management, branding, marketing and leadership to local communities.

Within the framework of the OVOP collaboration there are three main actors, namely: the Ministry of Cooperatives and MSMEs with the International Corporation and Development Fund (ICDF) or the Taiwan Technical Mission. These three actors have their own duties and functions as stipulated in the cooperation agreement. [8]

ICDF will give an estimate if later there is a potential that is considered good. What makes the ICDF interested in working with Bali is because it wants to develop regional production through OVOP. Bali is an OVOP pilot project which, if successful, can be continued to other regions in Indonesia. In Bali, the superior products include oranges, asparagus, coffee, and others. But the potential of superior products in Bali, according to the ICDF, is very much because anything can grow well in Bali. Especially because Bali is very fast in the tourism industry, so food products are one of the leading products.

The Head of Study and Development, Bali Cooperative and SME Office, Kartika Jaya, gave an example, OVOP in Pelaga was managed by 143 farmer groups consisting of three to five members per group. In an area of six hectares, farmer groups can produce 50 kilograms (kg) of asparagus per day. "It is super quality asparagus at a price of Rp. 35 thousand per kg," Kartika said. The people in Pelaga, Kartika said, had previously sought work in Kuta and Denpasar and rented farmland in their hometown. After the OVOP program was developed, they returned home to becoming a farmer. Pelaga's asparagus products are limited to being sold in Bali to meet the demands of hotels that reach $200 \mathrm{~kg}$ per day. Marketing is done by means of farmers bringing their crops to cooperatives.

Thanks to the collaboration between the Badung Regency Government and the coaching of agricultural experts from the ICDF Foundation from Taiwan which has been running for almost five years, Pelaga Village is able to produce the highest quality asparagus which is even touted as the best quality in Asia.

The rapid development of asparagus agriculture in Pelaga is also inseparable from the big role of Mr.Tsu Tien Chi from Taiwan who was appointed as the coach of asparagus farmers in Pelaga.

\section{Conclusion}

The community of Pelaga Village, Badung regency, especially the asparagus farmers and communities in Kintamani, Bangli district, especially orange farmers, Bali Province through the OVOP program compiled by the central government with relatively new socialization, not 
only provided motivation, increased value added activities. But it is also focused on independence and increasing farmers' income.

Linkages to the Concept of Community Empowerment Broadly speaking, the objective of an empowerment program in this case is the OVOP program is to achieve independence and increase the standard of living of the community, especially farmers in Pelaga Village. Aside from the support and assistance from the government, what is not less important in the development of OVOP in Pelaga Village is the Taiwan Technical Mission (TTM) Assistance Team led by an asparagus expert, Mr. Su Tien Chi. This team is tasked with training, fostering, assisting and empowering traditional farmers continuously for a period of 5 (five) years. In line with the OVOP Program in Pelaga Village, it is seen from the stages of empowerment activities according to Mardikanto, namely: Establishment and introduction of work areas. [9]. The selection of the Pelaga Village area as the OVOP Program's working area has been agreed upon by the related parties starting from the ministries, provinces and local governments with Taiwan cooperation. The activity begins by looking at the regional superior potential that can be developed, conducting a coordination meeting on the location of the development and selection of land as a pilot for asparagus planting.

The obstacles found in implementing the program are as follows: Difficulties in changing the mindset of traditional farmers to modern farmers. There are still farmers who have not been able to change their mindset to think about traditional farming patterns that tend to be easier than asparagus farming patterns. Pessimistic farmers due to experience of failure of previous programs. Experience previous program failures that made farmers pessimistic about new programs. Extreme weather that is still difficult to anticipate by asparagus farmers.

\section{References}

[1]. Guntur Setiawan, Implementasi dalam Birokrasi Pembangunan. Bandung: Remaja Rosdakarya Offset, 2004

[2]. Sumodiningrat and Wulandari, Menuju Ekonomi Berdikari Pemberdayaan UMKM dengan Konsep OPOP - OVOP - OVOC. Yogyakarta: Media Presindo, 2015

[3]. John W. Creswell and Cheryl N. Poth, Qualitative Inquiry and Research Design Choosing Among Five Approaches (4th edition). SAGE Publications, Inc Publication Date: December 23, 2016

[4]. New President Inaugurated, Taiwan-Indonesia Relations Increases: https://m.tempo.co/read/news/2016/06/01/090775847/presiden-baru-dilantik-hubungantaiwan-indonesiaiamen level, Wednesday, June 012016

[5]. "TAITRA": http://www.taiwanexcellence.com.tw/id/about-us-TAITRA.aspx)

[6]. Sumodiningrat dan Wulandari, Menuju Ekonomi Berdikari Pemberdayaan UMKM dengan Konsep OPOP - OVOP - OVOC. Yogyakarta: Media Presindo, 2015

[7]. Panduan Operasional, Blue Print One Village One Product. Deputi Bidang Pengkajian Sumberdaya UKMK : https://www.yumpu.com/id, diakses 20 Desember 2015.

[8]. Persadi Mardikanto dan Soebiato. Pemberdayaan Masyarakat dalam Perspektif Kebijakan Publik. Bandung: Alfabeta, 2015 